Bruno Škrinjarić*

Jelena Budak **

Mateo Žokalj ${ }^{* * *}$
JEL Classification D12

Original scientific paper

\title{
THE EFFECT OF PERSONALITY TRAITS ON ONLINE PRIVACY CONCERN
}

This paper examines personality traits as antecedents of online privacy concern. The aim of the research is to analyze if and how personal characteristics of Internet users affect their concern for privacy in online environment. The theoretical framework consisting of the Big Five theory of personality traits has been used to test the variations in online privacy concern. The model includes a range of other variables that might affect online privacy concern, such as sociodemographic factors, cultural values and computer literacy. The empirical analysis is based on survey data collected in 2016 on a large sample of 2,060 Internet users in Croatia. Results of both OLS and ordered probit estimations show that two personality traits dimensions, namely extraversion and neuroticism, significantly determine the level of online privacy concern. The more extraverted, i.e., more energetic and outgoing Internet user is less concerned about his/her online privacy, whilst the more neurotic one is more concerned. Privacy awareness, computer anxiety and previous negative experience were also observed as antecedents, all positively affecting the level of privacy concern of Internet users. The results of this research fill the gap in the underexplored area of personality traits and online privacy concern literature and contribute to developing an extended model of online privacy concern.

Keywords: privacy concern, Internet, personality traits, survey eizg.hr).

B. Škrinjarić, Research assistant, The Institute of Economics, Zagreb (E-mail: bskrinjaric@

** J. Budak, Ph.D., Senior research fellow, The Institute of Economics, Zagreb (E-mail: jbudak@eizg.hr).

**** M. Žokalj, InterCapital Securities LTD, Zagreb (E-mail: mateo-zokalj@interkapital.hr).

The paper was received on January 3rd, 2018. It was accepted for publication on March 12th, 2018. 


\section{Introduction}

The interaction of online privacy concern and personality traits as one of its antecedents has been the subject of scientific research since relatively recently. With the development of information science and the Internet, online privacy issues have raised the attention of both scholars (e.g. Gellman \& Dixon, 2011) and policymakers (e.g. Henderson, 2015). In addition, there are numerous business areas that might be interested in online privacy concern as well, such as e-commerce and location-based services. The results of the European Commission's survey on "ICT Usage and e-Commerce" (2016) show there is an increase in e-commerce trading. In 2015, 20 percent of enterprises in the European Union (EU) recorded e-sales, which accounted for 16 percent of the total turnover of enterprises. Compared to 2008, the figures increased by 7 and 4 percentage points, respectively. Globally, it is expected that in 2020, e-sales will reach USD 4.1 trillion with their share in total retail sales doubling compared to the 2015 level (eMarketer, 2016). Another common theme of investigating online privacy concern is the issue of location-based services (Hin et al., 2015). The bulk of mobile phone applications, and especially social media, contain features which enable data to be collected on the users' whereabouts through GPS tracking. Without discussing the ethical implications, many individuals find the disclosure of their location intrusive, or at least express their concerns over potential misuse. Viseu et al. (2004) argued that online privacy issue starts with the sitting in front of the computer, continues when using the Internet, and remains after the personal data have been submitted.

Within an extended model of online privacy concern research, and based on an intuitive notion that personality certainly determines our everyday life, the aim of this paper is to explore what determines the privacy concern of Internet users and, specifically, if and how their personality shapes and explains the level of their concern about privacy when online.

The research hypotheses argue whether five personality traits significantly influence an individual's online privacy concern. Based on the theoretical model and intuitive rationale, and only partially on relatively scarce existing literature, we assume a positive impact of conscientiousness, openness and neuroticism on online privacy concern, while extraversion and agreeableness are expected to affect it negatively. The divergence between the theory and empirical evidence is observed in the latter two personality traits which mostly prove to be positively correlated with the level of online privacy concern.

As Li (2011) notes, personality traits are underexplored in the online privacy concern literature and this paper contributes by filling this gap. The fact that so far, to the best of our knowledge, only two papers have addressed this important issue, is enough to motivate us to look further into the potential importance 
of personality traits for online privacy concern. Studies of Junglas, Johnson \& Spitzmuller (2008) and Korzaan \& Boswell (2008), although both examining personality traits and the online privacy concern nexus, are of different size and scope when compared to the comprehensive and extended model applied in this research. The value added is the empirical analysis performed on the large survey of over 2,000 Internet users.

In order to provide plausible answers on how personality traits fit in the privacy story and how they can explain the variations in online privacy concern, one should understand the reasons behind the research of online privacy concern in general, as well as personality traits, which are considered to be relevant antecedents. Therefore, the theoretical framework consisting of the Big Five theory of personality traits and online privacy concern is briefly explained in the following chapter. After the literature review and an overview of the hypotheses that will be tested, we proceed with the empirical analysis based on survey data collected in 2016 on a large sample of Internet users in Croatia. The survey sample, data and variables as well as methodology are provided in section three of the paper. The results are discussed in section four and the last section presents conclusions and lines of future research.

\section{Literature Review}

Since the golden age and the breakthrough of computer science, which took place in the last decade of the previous century, the pioneering work arguing the significance of personality differences among individuals has been Smith et al. (1996). Personality traits can be defined as "the substance of personality" (McCrae \& Costa, 1987), an individual's tendencies resulting in different attitudinal and behavioral patterns across a diverse set of situations. Thus, depending on their personality, individuals' opinions and actions regarding online privacy concern differ. The upside of personality traits in explaining online privacy concern is their hereditary origin (Bergeman et al., 1993), as well as their stability across an individual's lifetime (McCrae \& Costa, 1991) and across cultures (Salgado et al., 2003). Given the aforementioned characteristics, one can assume relative invariability of personality traits both through time and across different countries or cultures.

Various theoretical approaches to personality have resulted in different measurements and indicators of an individual's characteristics. In the psychological literature, Tupes \& Christal (1961) are recognized as the first authors discovering five-factor personality traits. In pursuit of a unified framework, which would be applicable and accepted in the scientific community, the Big Five framework further 
emerged in the late 1980s and was developed in different versions (e.g. Goldberg, 1992), ranging from very large 60-variable models to more reduced models (see Donellan et al., 2006 for a review). The Big Five framework divides personality into five traits, namely openness (to experience), conscientiousness, extraversion, agreeableness and neuroticism (sometimes referred to as emotional instability). From the large psychological studies, shortened versions of the Big Five framework have been developed in order to make them suitable for usage in other research fields and in cases when the questionnaire time is limited; for example, there is a highly used abbreviated 10-item version developed by Rammstedt \& John (2007).

The aforementioned personality traits are confronted in this paper with online privacy concern (OPC), a construct indicating an individual's level of perceived harm or vulnerability when using the Internet (Malhotra, Kim \& Agarwal, 2004).

Among many potential antecedents, a range of other factors might affect online privacy concern, such as sociodemographic factors, cultural values, computer literacy and others (see for example Chen \& Liu, 2015; Ur \& Wang, 2013; Ifinedo, 2011). The direction and strength of the relation between demographic characteristics and privacy concern are ambiguous. Most of the studies, however, find that females and the elderly are more privacy-concerned when compared to males and the younger population (for a review, see Anić, 2015).

Another underexplored, yet important determinant of online privacy concern is culture. Bellman et al. (2004) find that some cultural values have effects on privacy concern, but that their impact is mediated by the regulatory structure. The effect of societal culture on privacy concern is confirmed by Milberg, Smith \& Burke (2000): power distance, individualism and masculinity have a positive impact on privacy concern, and uncertainty avoidance negative. Budak, Rajh \& Žokalj (2016) observe differences in individuals' set of values among Internet users in Croatia and suggest more research on the direction and strength of causal relations of values, demographic characteristics and social trust as antecedents of online privacy concern. Social trust is supposed to stand as a key factor in building an individual's trust in institutions and other people. The importance of trust rises in the context of conducting Internet transactions, because of the increased uncertainty and risks related with online transactions (Pavlou, 2002). This goes hand in hand with previous experience of the Internet user or somebody close to him/her that might strongly affect the individual's privacy concern (Okazaki, Li \& Hirose, 2009). Namely, negative experience connected to privacy intrusion, stealing data or simply spams and advertising should considerably alter the privacy concern of the victim, and this leads us to the following hypotheses:

H1: Trust in institutions is negatively related to online privacy concern.

$\mathrm{H} 2$ : Previous (negative) experience is positively related to online privacy concern. 
Privacy awareness is the consciousness of an individual about the importance of privacy and privacy threats. People might or might not be aware of the fact that everything ever posted on the web remains there forever and might be (mis)used. Privacy awareness also involves awareness of privacy policy practices of both government and business sectors. Privacy awareness might have a positive or negative influence on online privacy concern, in particular of consumers (Dommeyer \& Gross, 2003). A person who is better acquainted with the privacy policy put in place might see the leakages in the system and that will increase his/her online privacy concern. On the other hand, if a person feels safe and well-informed about privacy protection, he/she should be less concerned about his/her privacy when online. Also, it should be noted that if protective behavior requires slowing down of an individual's online activities or an effort above individual's threshold, it is unlikely that he/she will take it since complete transparency demands no effort (Regan, 2002). Thus the following hypothesis is proposed:

\section{H3: Privacy awareness is positively related to online privacy concern.}

Finally, personal computer skills are expected to be positively related to the online activities of Internet users. People who have IT knowledge are expected to use the Internet more, and for a wider range of operations, and this might ease their online privacy concern. Within this context, an eased online privacy concern may emanate as a result of strong privacy protection which is positively correlated to Internet skills (Buchi et al., 2017). In contrast, computer anxiety, described as aversion towards computerization (Parasuraman \& Igbaria, 1990), may increase the privacy concern of Internet users. Previous research has found that computer anxiety affects users' performance (Thomas, 1994), so it might lead to increased privacy concern when online.

H4: Computer anxiety is positively related to online privacy concern.

The following section will further expand on the sample and variable characteristics. Since the research focus is on the personality traits and online privacy concern nexus, the literature review further describes a more narrowed body of the relevant literature.

The impact of personality traits on online privacy concern has been relatively recently examined and provides a lot of potential for future research. Stewart \& Segars (2002) tried to develop a first-order and second-order construct of the concern for information privacy and restated personality traits as one of the antecedents. To the authors' best knowledge, Junglas et al. (2008) is the trailblazing study in this field. Their seminal work certainly integrates the aforementioned theoretical work and empirical research upon which later papers will be based. They investigated the connection between the Big Five and concern for privacy 
(CFP) in the context of adoption of location-based services. Using a survey-based approach on a sample of 378 undergraduate and graduate students, the authors estimate a structural equation model (SEM) which indicates a positive impact of conscientiousness and openness, and a negative effect of agreeableness on CFP. Neuroticism and extraversion came up insignificant in explaining an individual's concern for privacy.

Korzaan and Boswell (2008) follow the same methodology on a sample of 230 undergraduate students, and find a significant and positive influence of solely agreeableness on concern for information privacy. Bansal et al. (2010) evaluate the impact of the Big Five on perceived health information sensitivity, which is a positively-affecting determinant of health information privacy concern, on a sample of 367 students using SEM. Agreeable and neurotic students are more sensitive regarding their health information, while the opposite stands for the more open ones.

In the context of Facebook activity, Sumner et al. (2011) analyze a survey on a sample of 537 individuals (mostly from the US and the UK) using Spearman correlation. Their results imply a positive effect of extraversion, neuroticism and agreeableness on OPC. Morton (2013) estimates SEM on survey data from 353 students, and constructs two higher-order factors of personality traits, namely stability (agreeableness, conscientiousness, reversed neuroticism) and plasticity (openness, extraversion), concluding a negative impact of stability on concern about the privacy behavior of organizations and government.

Hin et al. (2015) analyze survey data from 291 adults in Malaysia using Pearson correlation. They divide concern for information privacy (CFIP) into four factors - collection, improper access, errors and secondary use - and further investigate the impact of personality traits on each factor. Extraversion and openness correlate positively with collection, the aforementioned traits and conscientiousness are positively correlated with improper access and errors, while agreeableness and neuroticism are related with secondary use, positively and negatively, respectively. Osatuyi (2015) examines data from 298 undergrads using SEM-PLS and detects a positive impact of agreeableness and conscientiousness on information privacy concern on social media platforms.

In order to examine the relation between personality traits and online privacy concern, the following set of hypotheses is developed:

H5: Openness is positively related to online privacy concern.

H6: Conscientiousness is positively related to online privacy concern.

$\mathrm{H} 7$ : Extraversion is negatively related to online privacy concern.

H8: Agreeableness is negatively related to online privacy concern.

H9: Neuroticism is positively related to online privacy concern. 
Sociodemographic characteristics of an Internet user such as gender, age, employment status, might affect the privacy concern of Internet users, although the direction of this impact is ambiguous. The following hypothesis is proposed:

H10: Sociodemographic characteristics of an Internet user significantly impact his/her online privacy concern.

The same reasoning stands for including the time spent online into the model. A person who is a heavy Internet user might be more used to the privacy rules online and therefore less concerned, or in the contrary, more aware of the potential privacy breaches when online.

H11: Time the Internet user spends online significantly affects his/her online privacy concern.

Based on the theoretical model and intuitive rationale, we will test the hypotheses represented in the conceptual model (Figure 1). A positive impact of conscientiousness, openness and neuroticism on online privacy concern comprises the affirmative set of hypotheses, while a negative effect of extraversion and agreeableness is examined in the two remaining ones.

Figure 1

\section{CONCEPTUAL MODEL OF ANTECEDENTS TO ONLINE PRIVACY CONCERN}

- Personality traits

- Openness (+)

- Conscientiousness $(+)$

- Extraversion (-)

- Agreeableness (-)

- Neuroticism (+)

- Privacy awareness $(+)$

- Trust in institutions (-)

- Previous (neg.) experience $(+)$

- Computer anxiety (+)

- Time online

- Sociodemographics 


\section{Data and Variables in the Model}

Data for this paper were collected by computer-assisted telephone interviewing (CATI) method during the period from November 2015 to March 2016. Internet users in Croatia represent the population for this study, and secondary data (provided by Stilus Media) were used to assess the number of Internet users in Croatia. An online phone book was used as a sampling frame. The sample was created based on a one-way stratification by 21 counties. The sample allocated to each stratum was proportional to the assessed number of Internet users in each stratum. Within each stratum a combination of random and systematic sampling was applied. Pages from the phone book were selected using simple random sampling procedure. Sample units within each page were selected applying systematic sampling procedure. The final sample consists of 2,060 Internet users aged 18 or older (Table 1).

Table 1.

DESCRIPTIVE STATISTICS, $\mathbf{N}=\mathbf{2 , 0 6 0}$

\begin{tabular}{|l|c|c|c|c|}
\hline Variable & Mean & St. Dev. & Min. & Max. \\
\hline Online privacy concern & 3.56 & 0.96 & 1 & 5 \\
\hline Personality traits & 3.92 & 0.87 & 1 & 5 \\
\hline Extraversion & 3.96 & 0.70 & 1 & 5 \\
\hline Agreeableness & 4.09 & 0.84 & 1 & 5 \\
\hline Conscientiousness & 2.47 & 0.96 & 1 & 5 \\
\hline Neuroticism & 2.87 & 0.86 & 1 & 5 \\
\hline Openness & 0.50 & 0.50 & 1 & 1 \\
\hline Gender* & 0.50 & 0.50 & 0 & 0 \\
\hline Male & 39.83 & 12.91 & 18 & 84 \\
\hline Female & \multicolumn{5}{|l|}{} \\
\hline Age & 0.01 & 0.09 & 0 & 1 \\
\hline Education* & 0.50 & 0.50 & 0 & 1 \\
\hline Primary or less & 0.46 & 0.50 & 0 & 1 \\
\hline Secondary & 0.03 & 0.17 & 0 & 1 \\
\hline Tertiary & 3.52 & 1.26 & 1 & 12 \\
\hline PhD or post-grad & 0.02 & 0.14 & 0 & 1 \\
\hline Number of people in household
\end{tabular}


Table 1. Continued

\begin{tabular}{|l|c|c|c|c|}
\hline Variable & Mean & St. Dev. & Min. & Max. \\
\hline Manager & 0.02 & 0.14 & 0 & 1 \\
\hline Professional & 0.30 & 0.46 & 0 & 1 \\
\hline Technician/clerk & 0.18 & 0.39 & 0 & 1 \\
\hline Worker & 0.25 & 0.43 & 0 & 1 \\
\hline Retired & 0.09 & 0.28 & 0 & 1 \\
\hline Student & 0.09 & 0.28 & 0 & 1 \\
\hline Unemployed & 0.05 & 0.22 & 0 & 1 \\
\hline Other & 0.01 & 0.08 & 0 & 1 \\
\hline Size of place of residence* & \multicolumn{5}{|l|}{} \\
\hline 10,000 or less & 0.14 & 0.34 & 0 & 1 \\
\hline $10,001-50,000$ & 0.35 & 0.48 & 0 & 1 \\
\hline 50,001-100,000 & 0.15 & 0.36 & 0 & 1 \\
\hline More than 100,000 & 0.36 & 0.48 & 0 & 1 \\
\hline Previous experience - online privacy breach & 0.18 & 0.38 & 0 & 1 \\
\hline Trust in institutions & 2.75 & 0.94 & 1 & 5 \\
\hline Time spent actively online & 3.22 & 2.87 & 0.5 & 24 \\
\hline Privacy awareness & 3.92 & 0.64 & 1.4 & 5 \\
\hline Computer anxiety & 2.94 & 1.06 & 1 & 5 \\
\hline
\end{tabular}

Note: * These variables were transformed into dummy variables for each possible outcome, so the means in this case actually represent the percentage of respondents with a given outcome for every variable.

Table 1 gives a preliminary descriptive view on the characteristics of the sample. Given the sample and the scale from 1 to 5 , the average individual is relatively concerned for his/her online privacy concern with a mean value of 3.56. Furthermore, the highest value is achieved in conscientiousness (4.09), thus indicating that the average Croatian respondent is success-oriented as well as selfdisciplined and efficient. Relatively high scores of 3.96 and 3.92 are achieved in agreeableness and extraversion, respectively, hence implying a strong social component of the population. The aforementioned characteristics are observable through empathy and trustworthiness, as well as outgoingness manifested in a broad circle of friends and acquaintances. On the other hand, neuroticism and openness scored relatively low, with a mean of 2.47 and 2.87, respectively. As a result, one could argue general preference of the sample towards predictability and routines instead of creativity and adventure (low openness) and low levels of anxiety, stress and emotional stress.

Even though secondary to the research, interesting conclusions can be drawn from the scores of other variables. It appears that trust in institutions, composed 
of trust in public authorities, the judiciary and police, is relatively low among the population (a score of 2.75). A plausible explanation behind the lack of trust could lie in the perception of corruption of public bodies, which is often reinforced by the discoveries of malicious practice in law-enforcement, the judiciary and other public authorities.

The presence of the Internet in everyday life is quantified through the mean of 3.22, thus showing that an average Croatian respondent spends just above three hours a day online. Furthermore, the potential privacy risks emanating from the use of the Internet are generally well-perceived (3.92). Finally, fear of computerization and concern about the pace of automation, both forming computer anxiety, are relatively limited (a mean value of 2.94).

The dependent variable in the model is online privacy concern. Although the intensity or range of online privacy concern is subjective and difficult to measure, we have taken the measurement scales developed by Smith, Milberg \& Burke (1996) and described in Malhotra, Kim \& Agarwal (2004), and adapted them for the Internet environment (Table 2). The determinants of online privacy concern have been taken from the existing literature on antecedents of privacy concern and adapted for the online environment. ${ }^{1}$

Table 2.

\section{VARIABLES IN THE MODEL}

\begin{tabular}{|l|l|}
\hline Variable & Description \\
\hline & Index computed from these six items*: \\
& - I am concerned about my online privacy. \\
& - All things considered, the Internet could cause serious privacy problems. \\
- Compared to others, I am more sensitive about the way my personal \\
Online privacy \\
concern (opc)
\end{tabular}$\quad \begin{aligned} & \text { - I am concerned about extensive collection of my personal information } \\
& \text { over the Internet. }\end{aligned}$

1 The questionnaire is available from the authors upon request. 
Table 2. Continued

\begin{tabular}{|c|c|}
\hline Variable & Description \\
\hline Extraversion (ex) & $\begin{array}{l}\text { Index computed from these two items*: } \\
\text { - I see myself as someone who is reserved.** } \\
\text { - I see myself as someone who is outgoing, sociable. } \\
\text { (Cronbach alpha } 0.34 \text {, inter-item correlation } 0.25 \text { ) } \\
\end{array}$ \\
\hline Agreeableness (ag) & $\begin{array}{l}\text { Index computed from these two items*: } \\
\text { - I see myself as someone who is generally trusting. } \\
\text { - I see myself as someone who tends to find fault with others.** } \\
\text { (Cronbach alpha } 0.03 \text {, inter-item correlation } 0.01)\end{array}$ \\
\hline $\begin{array}{l}\text { Conscientiousness } \\
(\mathrm{co})\end{array}$ & $\begin{array}{l}\text { Index computed from these two items*: } \\
\text { - I see myself as someone who tends to be lazy.** } \\
\text { - I see myself as someone who does a thorough job. } \\
\text { (Cronbach alpha } 0.40, \text { inter-item correlation } 0.28 \text { ) }\end{array}$ \\
\hline Neuroticism (ne) & $\begin{array}{l}\text { Index computed from these two items*: } \\
\text { - I see myself as someone who is relaxed, handles stress well.** } \\
\text { - I see myself as someone who gets nervous easily. } \\
\text { (Cronbach alpha } 0.54 \text {, inter-item correlation } 0.50 \text { ) }\end{array}$ \\
\hline Openness (op) & $\begin{array}{l}\text { Index computed from these two items*: } \\
\text { - I see myself as someone who has few artistic interests.** } \\
\text { - I see myself as someone who has an active imagination. } \\
\text { (Cronbach alpha } 0.37 \text {, inter-item correlation } 0.44 \text { ) } \\
\end{array}$ \\
\hline Gender & $1=$ Male, $0=$ Female \\
\hline Age & Age of respondent \\
\hline Education (educ) & $\begin{array}{l}\text { Highest achieved level of education: } 1=\text { primary school or less; } \\
2=\text { secondary education; } 3=\text { tertiary education/college, university; } 4= \\
\text { master's degree/doctoral title }\end{array}$ \\
\hline Household (hh) & Number of people living in respondent's household \\
\hline Occupation (оси) & $\begin{array}{l}\text { Occupation of respondent: } 1=\text { owner of the company/craft (own-account } \\
\text { worker); } 2=\text { manager/official; } 3=\text { professional (highly educated e.g. medical } \\
\text { doctor, lawyer, bookkeeper, etc.); } 4=\text { technician/clerk; } 5=\text { worker; } 6=\text { retired; } \\
7=\text { student; } 8=\text { unemployed }\end{array}$ \\
\hline $\begin{array}{l}\text { Size of place of } \\
\text { residence (size) }\end{array}$ & $\begin{array}{l}\text { Number of inhabitants in respondent's place of residence: } 1=10,000 \text { or less; } \\
2=10,001-50,000 ; 3=50,001-100,000 ; 4=\text { more than } 100,000\end{array}$ \\
\hline $\begin{array}{l}\text { Previous online } \\
\text { privacy experience } \\
(\text { pe_onl) }\end{array}$ & $\begin{array}{l}\text { Have you or somebody close to you had bad experiences with regard to } \\
\text { privacy violation on the Internet before? }(1=\text { Yes, } 0=\text { No) }\end{array}$ \\
\hline $\begin{array}{l}\text { Trust in } \\
\text { institutions (inst_ } \\
\text { tru) }\end{array}$ & $\begin{array}{l}\text { Index computed from these three items*: } \\
\text { - How much do you trust public authorities? } \\
\text { - How much do you trust the police? } \\
\text { - How much do you trust courts? } \\
\text { (Cronbach alpha } 0.75 \text {, inter-item correlation } 0.66 \text { ) }\end{array}$ \\
\hline
\end{tabular}


Table 2. Continued

\begin{tabular}{|c|c|}
\hline Variable & Description \\
\hline Time (time) & Number of hours in a typical day the respondent spends on the Internet \\
\hline $\begin{array}{l}\text { Privacy awareness } \\
\text { (aw) }\end{array}$ & $\begin{array}{l}\text { Index computed from these five items*: } \\
\text { - I am aware of the privacy issues and practices in our society. } \\
\text { - I follow the news and developments about privacy issues and privacy } \\
\text { violations. } \\
\text { - I keep myself updated about privacy issues and the solutions that } \\
\text { companies and the government employ to ensure our privacy. } \\
\text { - Websites seeking information online should disclose the way the data are } \\
\text { collected, processed and used. } \\
\text { - A good online privacy policy should have a clear and conspicuous } \\
\text { disclosure. } \\
\text { (Cronbach alpha 0.66, inter-item correlation 0.27) }\end{array}$ \\
\hline $\begin{array}{l}\text { Computer anxiety } \\
\text { (ca) }\end{array}$ & $\begin{array}{l}\text { Index computed from these three items*: } \\
\text { - Computers are a real threat to privacy in this country. } \\
\text { - I am anxious and concerned about the pace of automation in the world. } \\
\text { - I am easily frustrated by increased computerization in my life. } \\
\text { (Cronbach alpha } 0.72 \text {, inter-item correlation } 0.82 \text { ) }\end{array}$ \\
\hline
\end{tabular}

Notes: * The items were measured on a 5-point Likert scale ranging from 1 (totally disagree) to 5 (totally agree). All indexes were calculated as a simple average of their items.

** Prior to calculating the index value, these items were recoded as they have reverse direction from that of the latent variable they are estimating.

For personality traits we used the Big Five psychological assessment, based on how well the offered statements describe a respondent's personality regarding openness, conscientiousness, extraversion, agreeableness and neuroticism. The shortened version of the Big Five developed and tested by Rammstedt \& John (2007) was employed. It includes self-ratings on whether a person sees him/herself as someone who is reserved, gets nervous easily, is generally trusting, has an active imagination, does a thorough job, is outgoing and sociable. Low Cronbach alpha coefficients for five personality traits (Table 2) might be explained by the fact we used the shortened The Big Five Inventory (BFI-10) abbreviated to 10 items, with just two items per scale. As explained in Rammstedt \& John (2007) “...the BFI10 possesses acceptable psychometric properties. However, there were substantial losses in comparison to the full-scale BFI. Thus, if testing time is not extremely limited, full-length Big Five measures possess clear psychometric advantages. ... Only for research settings in which participant time is truly limited and when personality assessment would otherwise be impossible, such as in telephone surveys, the BFI-10 offers an adequate assessment of personality." (Rammstedt \& John, 2007:210). 
Openness to experience (henceforth openness) corresponds to an individual's curiosity and propensity towards new experiences. Due to their adventurous and creative mind, individuals with relatively higher openness are more inclined towards art and culture. On the other hand, people who prefer routines, predictability and have a tendency to "go with the flow", score less on this personality trait. It is expected that more open people have a higher level of awareness, due to their diverse life experience, and are more concerned about online privacy since they are aware of the possible threats.

Conscientiousness pertains to an individual's attention to detail, adherence with standards and orientation towards success, excellence and efficiency. Also, conscientious individuals are more goal-oriented, with high levels of self-discipline and deliberation (Costa et al., 1991). Unlike them, people who score less on this trait are likely to procrastinate and have less determination. As with openness, conscientiousness is expected to have a positive sign with respect to privacy concern due to the person's attention to detail.

Extraversion is related to the experience of positive life events and extroverts have generally more friends and acquaintances. Also, they are characterized as energetic and outgoing, and often find themselves in social situations (Judge et al., 2002). On the other hand, introverts have less need for social interaction and are more vulnerable to external threats. In our research, we assume a negative correlation of online privacy concern and the level of extraversion.

Agreeableness refers to an individual's empathy towards others through expression of concern and sensitivity. Furthermore, common attributes given to agreeable individuals are soft-heartened, good-natured, cooperative, tolerant and trustful. Thus, the proposed research hypothesis is a negative connection between agreeableness and online privacy concern, since agreeable individuals can be characterized as optimistic people with a strong tendency towards interpersonal relations.

Finally, neuroticism (or sometimes referred to as emotional instability) is a personality trait which manifests itself through frequent mood changes, periods of anxiety and diminished stress management. Also, neurotic persons are much easily irritated, worried and upset. As Junglas et al. (2008) remarked, individuals who score higher on neuroticism are less satisfied with their job. Due to their negative state of mind, we argue a positive correlation with online privacy concern, since neurotic persons are (over)aware of the dangers posed by the Internet.

Demographic characteristics of the respondents - in our case Internet users - might explain the level of online privacy concern (e.g. Zhang et al., 2002; Hoy \& Milne, 2010), so gender, age, education attained, occupation and size of the household have been included in the model as well. The differences between urban and rural in Croatia are difficult to capture by the location of the respondent because urban and rural areas in the sense of development and infrastructure are 
not clearly delineated. The size of place of residence is more indicative and our intuition gave us mixed signals?. In small places people might be more active and free of concerns when online because they have few alternatives in social and cultural life. However, this might be equally true for respondents living in large cities.

The items on previous experience were put in rather simple yes or no questions (adapted from Li, 2014). We distinguished negative experiences of the respondents (or somebody close to them) with regard to privacy violation on the Internet, from previous experience with privacy violation in general. Time spent online is used as a proxy for intensity of using the Internet.

To measure trust in institutions, three items were employed: one measuring the general trust in public authorities, and the other two specifically measuring trust in the police and the judiciary (Naef \& Schupp, 2009).

Fear of technology as well as concern about the negative aspects of computerization and frustration related to computer anxiety were measured using the adapted items of Parasuraman \& Igbaria (1990).

Next we proceed with the analysis of the proposed variables in our model.

\section{Results and Discussion}

First we use simple OLS regression using the model:

$$
o p c_{i}=\alpha+P T_{i}^{\prime} \beta+X_{i}^{\prime} \delta+\epsilon_{i},
$$

where online privacy concern is a dependent variable, $\beta$ is a 5 -dimensional vector of estimated coefficients for each of the personality trait $(P T)$ dimensions, $X$ is a matrix of all other covariates used in the regression, while $\delta$ is the vector capturing estimated coefficients of those covariates. All of the latent variables used in the model above (opc, ex ag, co, ne, op, inst_tru, aw and $c a$ ) enter the equation in their standardized form, i.e., with a mean of 0 and standard deviation of 1 , hence they are interpreted in terms of standard deviations.

The results from the OLS regression are presented in Table 3. In each successive model we add more control variables. Out of five personality trait dimensions, only two showed to be of statistical significance, namely extraversion and neuroticism: Therefore the hypotheses $\mathrm{H} 7$ and $\mathrm{H} 9$ have been confirmed, while the hypotheses H5, H6 and $\mathrm{H} 8$ have been rejected. A unit standard deviation increase in a person's extraversion characteristic will lead to a decrease of 0.038 standard deviations in their online privacy concern, referencing Model 3 where this showed to be significant. This finding is what we expected. Intuitively, a person who is 
more extraverted, i.e., more energetic, outgoing and often found in social situations, might be less concerned about their online privacy. In fact, such a person might enjoy sharing private information (in the form of pictures, attendance at different events, etc.) on various forms of social media.

Turning our attention now to neuroticism, a unit standard deviation increase in a person's neuroticism characteristic will lead to an increase between 0.033 and 0.037 standard deviations in their online privacy concern. This result was also expected. Intuitively, we expect someone who is more neurotic, i.e., has frequent mood changes and gets irritated easily, to be more concerned about their online privacy. Such people may decide to share as little information online (or with other people) as possible because revealing something personal might be the cause of their neuroticism in the first place.

Further analyzing the results presented in Table 3, we can see that neither gender, age, nor the number of people in the household affect a person's degree of online privacy concern. The same can be said for the respondent's educational level, occupation, place of residence and trust in institutions, so H10 and H1 have been rejected. It is interesting to notice that time spent online during a day (time) also plays no role in determining online privacy concern and $\mathrm{H} 11$ has been rejected. At first glance, one might expect that people who spend most of their time online get more experienced about different aspects of Internet use and personal information protection, so they might be less concerned about their privacy. However, the other side of the coin is that those people might become increasingly aware of potential dangers lurking beneath those codes of ones and zeros. The latter explanation might actually be more relevant to our case, as we find a strong statistical significance of previous online privacy breaches for the current level of online privacy concern ( $o p c$ is increased by 0.267 standard deviations if the respondent had previous negative experience with online privacy breach). This confirms the hypothesis $\mathrm{H} 2$.

Two other variables that showed to be statistically significant are privacy awareness and computer anxiety, both positively affecting the level of privacy concern when online. The relating hypotheses $\mathrm{H} 3$ and $\mathrm{H} 4$ have been confirmed.

Analyzing the former, it is not hard to imagine that those who keep themselves updated (aware) about various data gathering policies and privacy-related issues on the Internet are more concerned about their privacy when online. However, the strongest effect on online privacy concern comes from the latter - one standard deviation increase in computer anxiety is translated into an increase of 0.423 to 0.440 standard deviations in online privacy concern. Intuitively, people who think that the pace of computerization nowadays is dangerously high and represents a threat to privacy in this country are more likely to be worried about the information they provide online. 
Table 3.

OLS ESTIMATION RESULTS

\begin{tabular}{|c|c|c|c|c|c|c|}
\hline & \multicolumn{2}{|c|}{ Model 1} & \multicolumn{2}{|c|}{ Model 2} & \multicolumn{2}{|c|}{ Model 3} \\
\hline Extraversion & -0.029 & $(0.020)$ & -0.031 & $(0.020)$ & $-0.038^{*}$ & $(0.020)$ \\
\hline Agreeableness & -0.030 & $(0.021)$ & -0.029 & $(0.021)$ & -0.024 & $(0.021)$ \\
\hline Conscientiousness & 0.030 & $(0.020)$ & 0.024 & $(0.021)$ & 0.017 & $(0.021)$ \\
\hline Neuroticism & 0.032 & $(0.020)$ & $0.037^{*}$ & $(0.020)$ & $0.033^{*}$ & $(0.020)$ \\
\hline Openness & -0.020 & $(0.019)$ & -0.020 & $(0.020)$ & -0.022 & $(0.020)$ \\
\hline Privacy awareness & $0.212^{* * *}$ & $(0.020)$ & $0.208^{* * *}$ & $(0.020)$ & $0.204^{* * *}$ & $(0.020)$ \\
\hline Computer anxiety & $0.440^{* * * *}$ & $(0.019)$ & $0.434^{* * *}$ & $(0.020)$ & $0.423^{* * *}$ & $(0.020)$ \\
\hline Male & & & -0.013 & $(0.039)$ & -0.014 & $(0.039)$ \\
\hline Age & & & 0.001 & $(0.002)$ & 0.001 & $(0.002)$ \\
\hline Household & & & 0.019 & $(0.015)$ & 0.021 & $(0.015)$ \\
\hline \multicolumn{7}{|c|}{ Education effect (benchmark is primary education) } \\
\hline Secondary & & & -0.095 & $(0.137)$ & -0.151 & $(0.139)$ \\
\hline Tertiary & & & -0.139 & $(0.140)$ & -0.202 & $(0.142)$ \\
\hline Post-grad & & & -0.017 & $(0.176)$ & -0.092 & $(0.179)$ \\
\hline \multicolumn{7}{|c|}{ Occupation effect (benchmark is self-employed) } \\
\hline Manager & & & -0.025 & $(0.178)$ & 0.002 & $(0.178)$ \\
\hline Professional & & & -0.020 & $(0.126)$ & -0.003 & $(0.126)$ \\
\hline Technician & & & 0.027 & $(0.124)$ & 0.039 & $(0.124)$ \\
\hline Worker & & & 0.075 & $(0.122)$ & 0.072 & $(0.121)$ \\
\hline Retired & & & 0.011 & $(0.143)$ & 0.025 & $(0.142)$ \\
\hline Student & & & -0.138 & $(0.132)$ & -0.128 & $(0.132)$ \\
\hline Unemployed & & & -0.066 & $(0.142)$ & -0.053 & $(0.141)$ \\
\hline Other & & & 0.014 & $(0.258)$ & 0.015 & $(0.257)$ \\
\hline \multicolumn{7}{|c|}{ Size of place of residence effect (benchmark is less than 10,000 ) } \\
\hline $10,001-50,000$ & & & 0.018 & $(0.060)$ & 0.012 & $(0.060)$ \\
\hline $50,001-100,000$ & & & 0.008 & $(0.071)$ & 0.012 & $(0.070)$ \\
\hline$>100,000$ & & & 0.042 & $(0.060)$ & 0.029 & $(0.060)$ \\
\hline $\begin{array}{l}\text { Previous online } \\
\text { experience }\end{array}$ & & & & & $0.267^{* * *}$ & $(0.051)$ \\
\hline Trust in institutions & & & & & -0.021 & $(0.020)$ \\
\hline Time & & & & & -0.002 & $(0.007)$ \\
\hline$N$ & 2,060 & & 2,060 & & 2,060 & \\
\hline Adj. $R^{2}$ & 0.2592 & & 0.2590 & & 0.2689 & \\
\hline
\end{tabular}

Notes: Standard errors in parentheses; ${ }^{*} p<0.10,{ }^{* *} p<0.05,{ }^{* * *} p<0.01$. 
The analysis thus far has been carried out on standardized outcome variables and most of the interpretations are expressed in terms of standard deviations. Although this is statistically very well-ordered, intuitively it might be difficult to grasp. With that in mind, and also as a robustness check, we also run an ordered probit model to assess the probability of getting each possible outcome of the online privacy concern $(o p c)$ variable.

In the ordered probit model, we assume the underlying relationship as

$$
y_{i}^{*}=X_{i}^{\prime} \beta+\epsilon_{i}
$$

where dependent variable is exact but unobserved - instead, we can only observe different categories $j \in\{1,2, \ldots, M\}$ of this variable, and we define thresholds such that

$$
y_{i}=j \text { if } \alpha_{j-1}<y_{i}^{*} \leq \alpha_{j}
$$

Then, the probability that the observation $i$ will choose alternative $j$ is given by

$$
p_{i j}=p\left(y_{i}=j\right)=p\left(\alpha_{j-1}<y_{i}^{*} \leq \alpha_{j}\right)=F\left(\alpha_{j}-X_{i}^{\prime} \beta\right)-F\left(\alpha_{j-1}-X_{i}^{\prime} \beta\right)
$$

where $F$ is standard normal cumulative distribution function. The model is estimated using maximum likelihood.

In our case, the online privacy concern ( $o p c$ ) dependent variable can take five different categories (outcomes) ranging from 1 - Not concerned at all to 5 - Very concerned. These outcomes were obtained by rounding the value of the opc variable to the nearest whole number for each respondent.

All of the latent covariates (ex ag, co, ne, op, inst_tru, aw and $c a$ ) still enter the equation in their standardized form and are hence interpreted in terms of standard deviations, but the dependent variable $o p c$ now enters as a discrete variable. Table 4 shows the results of ordered probit estimations. 
Table 4.

\section{ORDERED PROBIT ESTIMATION RESULTS}

\begin{tabular}{|c|c|c|c|c|c|}
\hline & Outcome 1 & Outcome 2 & \begin{tabular}{|l|} 
Outcome 3 \\
\end{tabular} & Outcome 4 & Outcome 5 \\
\hline \multirow[t]{2}{*}{ Extraversion } & 0.001 & $0.007^{*}$ & \begin{tabular}{|l|}
$0.009^{*}$ \\
\end{tabular} & $-0.006^{*}$ & $-0.011^{*}$ \\
\hline & $(0.000)$ & $(0.004)$ & $(0.005)$ & $(0.003)$ & $(0.007)$ \\
\hline \multirow[t]{2}{*}{ Agreeableness } & 0.000 & 0.000 & 0.000 & -0.000 & -0.000 \\
\hline & $(0.000)$ & $(0.004)$ & $(0.006)$ & $(0.003)$ & $(0.007)$ \\
\hline \multirow[t]{2}{*}{ Conscientiousness } & -0.000 & -0.005 & -0.006 & 0.004 & 0.008 \\
\hline & $(0.000)$ & $(0.004)$ & $(0.005)$ & $(0.003)$ & $(0.007)$ \\
\hline \multirow[t]{2}{*}{ Neuroticism } & $-0.001^{*}$ & $-0.008^{*}$ & $-0.010^{*}$ & $0.006^{*}$ & $0.012^{*}$ \\
\hline & $(0.000)$ & $(0.004)$ & $(0.005)$ & $(0.003)$ & $(0.007)$ \\
\hline \multirow[t]{2}{*}{ Openness } & 0.000 & 0.006 & 0.008 & -0.005 & -0.009 \\
\hline & $(0.000)$ & $(0.004)$ & $(0.005)$ & $(0.003)$ & $(0.006)$ \\
\hline \multirow[t]{2}{*}{ Privacy awareness } & $-0.003^{* * *}$ & $-0.040^{* * * *}$ & $-0.051^{* * *}$ & $0.032^{* * *}$ & $0.063^{* * *}$ \\
\hline & $(0.001)$ & $(0.005)$ & $(0.006)$ & $(0.004)$ & $(0.007)$ \\
\hline \multirow[t]{2}{*}{ Computer anxiety } & $-0.007^{* * *}$ & $-0.083^{* * *}$ & $-0.106^{* * *}$ & $0.065^{* * *}$ & $0.129^{* * * *}$ \\
\hline & $(0.001)$ & $(0.006)$ & $(0.007)$ & $(0.006)$ & $(0.007)$ \\
\hline \multirow[t]{2}{*}{ Male } & 0.000 & 0.003 & 0.004 & -0.003 & -0.005 \\
\hline & $(0.001)$ & $(0.008)$ & $(0.010)$ & $(0.006)$ & $(0.013)$ \\
\hline \multirow[t]{2}{*}{ Age } & 0.000 & 0.000 & 0.001 & -0.000 & -0.001 \\
\hline & $(0.000)$ & $(0.000)$ & $(0.001)$ & $(0.000)$ & $(0.001)$ \\
\hline \multirow[t]{2}{*}{ Household } & -0.000 & -0.000 & -0.000 & 0.000 & 0.000 \\
\hline & $(0.000)$ & $(0.003)$ & $(0.004)$ & $(0.003)$ & $(0.005)$ \\
\hline \multicolumn{6}{|c|}{ Education effect (benchmark is primary education) } \\
\hline \multirow[t]{2}{*}{ Secondary } & $0.004^{* * * *}$ & $0.072^{* * *}$ & $0.158^{* * * *}$ & 0.005 & $-0.239^{* *}$ \\
\hline & $(0.001)$ & $(0.016)$ & $(0.056)$ & $(0.039)$ & $(0.108)$ \\
\hline \multirow[t]{2}{*}{ Tertiary } & $0.005^{* * *}$ & $0.082^{* * *}$ & $0.170^{* * *}$ & -0.003 & $-0.254^{* *}$ \\
\hline & $(0.001)$ & $(0.017)$ & $(0.057)$ & $(0.038)$ & $(0.110)$ \\
\hline \multirow[t]{2}{*}{ Post-grad } & $0.004^{*}$ & $0.074^{* * *}$ & $0.161^{* *}$ & 0.004 & $-0.243^{* *}$ \\
\hline & $(0.002)$ & $(0.028)$ & $(0.064)$ & $(0.042)$ & $(0.115)$ \\
\hline \multicolumn{6}{|c|}{ Occupation effect (benchmark is self-employed) } \\
\hline \multirow[t]{2}{*}{ Manager } & 0.002 & 0.023 & 0.036 & -0.015 & -0.046 \\
\hline & $(0.002)$ & $(0.034)$ & $(0.053)$ & $(0.022)$ & $(0.068)$ \\
\hline \multirow[t]{2}{*}{ Professional } & 0.002 & 0.027 & 0.040 & -0.017 & -0.051 \\
\hline & $(0.002)$ & $(0.024)$ & $(0.041)$ & $(0.013)$ & $(0.054)$ \\
\hline \multirow[t]{2}{*}{ Technician } & 0.002 & 0.033 & 0.049 & $-0.023^{*}$ & -0.061 \\
\hline & $(0.002)$ & $(0.024)$ & $(0.041)$ & $(0.013)$ & $(0.053)$ \\
\hline
\end{tabular}


Table 4. Continued

\begin{tabular}{|c|c|c|c|c|c|}
\hline & Outcome 1 & Outcome 2 & Outcome 3 & Outcome 4 & Outcome 5 \\
\hline \multirow[t]{2}{*}{ Worker } & 0.001 & 0.017 & 0.027 & -0.010 & -0.034 \\
\hline & $(0.001)$ & $(0.023)$ & $(0.041)$ & $(0.012)$ & $(0.054)$ \\
\hline \multirow[t]{2}{*}{ Retired } & 0.001 & 0.022 & 0.034 & -0.014 & -0.044 \\
\hline & $(0.002)$ & $(0.027)$ & $(0.044)$ & $(0.016)$ & $(0.057)$ \\
\hline \multirow[t]{2}{*}{ Student } & $0.006^{* *}$ & $0.074^{* *}$ & $0.089^{* *}$ & $-0.059^{* * * *}$ & $-0.110^{* *}$ \\
\hline & $(0.003)$ & $(0.029)$ & $(0.042)$ & $(0.021)$ & $(0.055)$ \\
\hline \multirow[t]{2}{*}{ Unemployed } & 0.004 & 0.046 & 0.063 & -0.034 & -0.079 \\
\hline & $(0.002)$ & $(0.030)$ & $(0.044)$ & $(0.020)$ & $(0.057)$ \\
\hline \multirow[t]{2}{*}{ Other } & -0.000 & -0.002 & -0.003 & 0.001 & 0.004 \\
\hline & $(0.003)$ & $(0.042)$ & $(0.076)$ & $(0.020)$ & $(0.102)$ \\
\hline \multicolumn{6}{|c|}{ Size of place of residence effect (benchmark is less than 10,000 ) } \\
\hline \multirow[t]{2}{*}{$10,001-50,000$} & 0.000 & 0.001 & 0.002 & -0.001 & -0.002 \\
\hline & $(0.001)$ & $(0.012)$ & $(0.016)$ & $(0.010)$ & $(0.020)$ \\
\hline \multirow[t]{2}{*}{$50,001-100,000$} & 0.001 & 0.010 & 0.013 & -0.008 & -0.016 \\
\hline & $(0.001)$ & $(0.015)$ & $(0.019)$ & $(0.012)$ & $(0.023)$ \\
\hline \multirow[t]{2}{*}{$>100,000$} & 0.000 & 0.004 & 0.005 & -0.003 & -0.006 \\
\hline & $(0.001)$ & $(0.013)$ & $(0.017)$ & $(0.010)$ & $(0.020)$ \\
\hline \multirow[t]{2}{*}{ Previous online experience } & $-0.004^{* * *}$ & $-0.052^{* * *}$ & $-0.067^{* * *}$ & $0.041^{* * * *}$ & $0.082^{* * *}$ \\
\hline & $(0.001)$ & $(0.011)$ & $(0.014)$ & $(0.009)$ & $(0.017)$ \\
\hline \multirow[t]{2}{*}{ Trust in institutions } & $0.001^{* *}$ & $0.010^{* *}$ & $0.013^{* *}$ & $-0.008^{* *}$ & $-0.016^{* *}$ \\
\hline & $(0.000)$ & $(0.004)$ & $(0.005)$ & $(0.003)$ & $(0.006)$ \\
\hline \multirow[t]{2}{*}{ Time } & 0.000 & 0.001 & 0.002 & -0.001 & -0.002 \\
\hline & $(0.000)$ & $(0.001)$ & $(0.002)$ & $(0.001)$ & $(0.002)$ \\
\hline$N$ & 2,060 & 2,060 & 2,060 & 2,060 & 2,060 \\
\hline
\end{tabular}

Notes: Standard errors in parentheses; ${ }^{*} p<0.10,{ }^{* *} p<0.05,{ }^{* * *} p<0.01$.

We start interpreting these results by confirming that only two dimensions of personality traits are statistically significant in explaining variation in online privacy concern - extraversion and neuroticism. Since openness, conscientiousness and agreeableness did not show to be significant determinants of online privacy concern, the hypotheses H5, H6 and H8 have been rejected. Starting with the interpretation of the former covariate, an increase of one standard deviation in extraversion from the mean is estimated to lead to a 0.7 and 0.9 percent increase in probability to be unconcerned or neither concerned nor unconcerned for online privacy, respectively. However, for the last two outcomes, the signs of the relationship are reversed - an increase of one standard deviation in extraversion from the mean is estimated to lead to a 0.6 and 1.1 percent decrease in probability to be 
concerned or very concerned for online privacy, respectively. These findings are consistent with the previous results from the simple OLS model, i.e., people with more characteristics of an extrovert are less likely to be concerned about their online privacy, and the hypothesis $\mathrm{H} 7$ has been confirmed again.

Looking at the results for the neuroticism personality trait, we can see that a unit standard deviation increase from the mean in this variable leads to a decrease in probability of being not concerned at all, unconcerned or neither concerned nor unconcerned for online privacy by $0.1,0.8$ and 1.0 percent, respectively; and to an increase in probability of being either concerned or very concerned for online privacy by 0.6 and 1.2 percent, respectively. This is also consistent with our previous results, i.e., less emotionally stable people tend to be more concerned about what information they are providing in an online environment and $\mathrm{H} 9$ is confirmed in this analysis as well.

It is interesting to see that some education and occupation effects become significant in this case. Referring first to the latter, only students exhibit statistically significant effects for all five possible outcomes. Compared to the people who are self-employed, students are more prone to be not concerned at all (0.6 percent) or unconcerned (7.4 percent), and less likely to be concerned (-5.9 percent) or very concerned (-11 percent) about their online privacy. This can be justified by the fact that students are those who use the Internet and various forms of social media for recreational and educational purposes the most. These are young people who have grown up using information technology from their childhood, and communicating, shopping, studying, posting on Facebook, tweeting, browsing through YouTube videos and other forms of entertainment are their way of life.

The education effect is also highly significant, and this adds to the partial confirmation of the hypothesis H10. Compared to someone with only primary education, every additional obtained education degree - secondary, tertiary and post-grad - decreases the likelihood of being very concerned for online privacy by 23.9, 25.4 and 24.3 percent, respectively. These people are most likely to be neither concerned nor unconcerned about their online privacy - this is the case for 15.8 percent of secondary school graduates, 17.0 percent of university graduates and 16.1 percent of people with a master's or doctoral degree. The rationale here is that as people become more educated, they also become more familiar with Internet use, as they have likely used it very frequently during their education process, and it becomes only natural to use the Internet for everyday purposes.

Another variable that becomes significant is trust in institutions. The obtained results confirm hypothesis $\mathrm{H} 1$ and suggest that an increase in this trust is most likely to result in people being unconcerned (1 percent) or neither concerned nor unconcerned (1.3 percent) about privacy while online. This is to be expected, since an effective judiciary system, coupled with unbiased police interventions 
and uncorrupt public authorities, provides a sense of security even in the online environment.

Existence of previous online privacy breaches? leads to higher levels of online privacy concern, with the most likely outcome of being very concerned (8.2 percent likelihood) so the hypothesis $\mathrm{H} 2$ is accepted, as well as H3 and H4, showing that privacy awareness and computer anxiety are positively and significantly associated to the level of online privacy concern.

Gender, age, size of the place of residence, number of people in the household and time spent actively online all showed to be insignificant, so H10 is partially, and H11 entirely rejected.

\section{Conclusion}

This empirical study sheds light on the effect of personality on privacy concern, specifically in the online environment, which is seen as a contribution to the existing research on this topic. In particular, the comprehensive approach of including other latent variables as antecedents to online privacy concern is considered a novelty, and findings are robust due to the large dataset employed. The analysis indicates that an average Internet user in Croatia is concerned about privacy when online, and that the Croatian Internet population is very conscientious, agreeable and extraverted. The positive effect of conscientiousness on online privacy concern was not significant. This might indicate that no matter how Internet users are efficient, self-disciplined and responsible in their work and in timely completing their tasks and duties, they might share concerns about privacy when online. Although openness has been assumed and confirmed in previous studies to be positively related to privacy concern, this was not confirmed in this research. Actually, the positive relation is somehow counter-intuitive because one would assume that more open people would not care much about their privacy. Although this antecedent has a negative coefficient, the relationship is not significant. As expected, but opposite to previous findings of Junglas et al. (2008), neuroticism and extraversion came up significant in explaining an individual's concern for privacy. The ambiguous effect of agreeableness in the literature has not been resolved either way in this empirical study. However, this research clearly shows that certain personality traits of Internet users determine the level of their concern about online privacy. The more extraverted and neurotic a person is, the more concerned about online privacy he/she is

The main purpose of this paper is to test whether personality stands as an antecedent of online privacy concern and whether it should be included in the 
extended model of online privacy concern. However, the analysis conducted on a large sample has also enabled us to learn more about the personality traits of Internet users in Croatia and this might be used for other studies as well. For example, getting more in-depth insight into the personality of Internet users in the context of their online privacy concern might be useful in designing marketing strategies and consumer-oriented business policies. We are aware that employing the shortened version of the Big Five model calls for cautious interpretation of the results and we recognize this as a limitation of our research. Further exploring of personality traits should apply only the large version of the Big Five questionnaire.

Although the empirical analysis uses a large set of nationwide individual data, which is considered a scientific contribution to the existing research, the survey was conducted on only one country's Internet user population. We recognize this as a limitation of the research, that might be seen also as a potential for extending the research to other nations by using the same methodology and survey instrument. Another line of future research is to test the extended model of online privacy concern with the consequences of online privacy concern included in the model.

\section{References:}

Anić, I.-D. (2015). “The development of database marketing: does consumer information privacy matter?”, u: Zbornik radova Ekonomskog fakulteta Sveučilišta u Mostaru, (21): 39-56.

Bansal, G., Zahedi, F. M., Gefen, D. (2010). "The impact of personal dispositions on information sensitivity, privacy concern and trust in disclosing health information online”, Decision Support Systems, (49), 2: 138-150.

Bellman, S., Johnson, E., Kobrin, S., Lochse, G. (2004). "International Differences in Information Privacy Concerns: A Global Survey of Consumers", Information Society, (20), 5: 313-324.

Bergeman, C. S., Chlpuer, H. M., Plomin, R., Pedersen, N. L., McClearn, G. E., Nesselroade, J. R., Jr. Costa, P. T., McCrae, R. R. (1993). “Genetic and Environmental Effects on Openness to Experience, Agreeableness, and Conscientiousness: An Adoption/ Twin Study", Journal of Personality, (61), 2: 159-179. doi:10.1111/j.1467-6494.1993. tb01030.x

Buchi, M., Just, N., Latzer, M. (2017). "Caring is not enough: the importance of Internet skills for online privacy protection”, Information, Communication \& Society, (20), 8: $1261-1278$.

Budak, J., Rajh, E., Žokalj, M. (2016). "Personal values of Internet users: a cluster analytic approach", working papers EIZ-WP-1606 Available at http://www.eizg.hr/hrHR/Radni-materijali-EIZ-a-207.aspx (last accessed 20.3.2017) 
Chen, L., Liu, H.-W. (2015). "A review of privacy protection in e-commerce”, Journal of Advanced Management Science, (3), 1: 50-53.

Donnellan, M. B., Oswald, F. L., Baird, B. M., Lucas, R. E. (2006). “The Mini-IPIP Scales: Tiny-yet-effective measures of the Big Five Factors of Personality", Psychological Assessment, (18), 2: 192-203. doi: 10.1037/1040-3590.18.2.192

Dommeyer, C., Gross, B. (2003). "What consumers know and what they do: an investigation of consumer knowledge, awareness, and use of privacy protection strategies", Journal of Interactive Marketing, (17), 2: 34-51.

eMarketer (2016). "Worldwide Retail Ecommerce Sales: The eMarketer Forecast for 2016", Available at: https://www.emarketer.com/Article/Worldwide-Retail-Ecommerce-Sales-Will-Reach-1915-Trillion-This-Year/1014369\#sthash.43pnUme0.dpuf (last accessed 20.3.2017)

European Commission, Eurostat. (2016). Available at: http://ec.europa.eu/eurostat/statistics-explained/index.php/E-commerce_statistics (last accessed 20.3.2017)

Gellman, R., Dixon, P. (2011). Online privacy. Santa Barbara: ABC Clio.

Goldberg, L. R. (1992). "The development of markers for the Big-Five factor structure", Psychological Assesment, (7), 1: 26-42.

Henderson, H. (2015). Online Privacy and Government. San Diego: Reference Point Press.

Hin, S. S., Tanamal, T. K. Y. M., Yi, H. J., Ling, L. W., Yahya, M. M., Ho, J. S. Y. (2015). "Consumer Personality, Privacy Concerns and Usage of Location-Based Services (LBS) ", Journal of Economics, Business and Management, (3), 10: 961-966.

Hoy, M., Milne, G. (2010). "Gender differences in privacy-related measures for young adult Facebook users", Journal of Interactive Advertising, (10), 2: 28-45.

Ifinedo, P. (2011). "Relationships between information security concerns and national cultural dimensions: findings in the global financial services industry", u: Nemati, H. R. (Eds.), Security and Privacy Assurance in Advancing Technologies, Hershey-New York: Information Science Reference, p. 134-153.

Judge, T. A., Heller, D., Mount, M. K. (2002). "Five-Factor Model of Personality and Job Satisfaction: A Meta-Analysis", Journal of Applied Psychology, (87), 3: 530-541.

Junglas, I. A., Johnson, N. A., Spitzmüller, C. (2008). "Personality traits and concern for privacy: an empirical study in the context of location-based services", European Journal of Information Systems, (17), 4: 387-402.

Korzaan, M. L.,Boswell, K. T. (2008). "The Influence of Personality Traits and Information Privacy Concerns on Behavioral Intentions", Journal of Computer Information Systems, (48), 4: 15-24.

Li, Y. (2011). "Empirical studies on online information privacy concerns: literature review and an integrative framework", Communications of the Association for Information Systems, (28), 1: 453-496.

Li, Y. (2014). "The impact of disposition to privacy, website reputation and website familiarity on information privacy concerns", Decision Support Systems, (57): 343-354. 
Malhotra, N.K., Kim S.S., Agarwal, J. (2004). "Internet users' information privacy concerns (IUIPC): The construct, the scale, and a causal model", Information Systems Research, (15), 4: 336-355.

McCrae, R. R., Costa, P. T. (1987). "Validation of the Five-Factor Model of Personality Across Instruments and Observers", Journal of Personality and Social Psychology, (52), 1: 81-90.

McCrae, R. R., Costa, P. T. (1991). "Adding liebe and arbeit: the full five-factor model and well-being”, Personality and Social Psychology Bulletin, (17), 2: 227-232.

Morton, A. (2013). Measuring Inherent Privacy Concern and Desire for Privacy - A Pilot Survey Study of an Instrument to Measure Dispositional Privacy Concern. Washington DC, Usa, IEEE Computer Society Washington.

Naef, M., Schupp, J. (2009). "Measuring Trust: Experiments and Surveys in Contrast and Combination”, IZA Discussion Paper Series, IZA DP No. 4087, Bonn: Institute for the Study of Labor (IZA).

Okazaki, S., Li, H., Hirose, M. (2009). "Consumer privacy concerns and preference for degree of regulatory control", Journal of Advertising, (38), 4: 63-77.

Osatuyi, B. (2015). "Personality Traits and Information Privacy Concern on Social Media Platforms", Journal of Computer Information Systems, (55), 4: 11-19.

Parasuraman, S., Igbaria, M. (1990). "An examination of gender differences in the determinants of computer anxiety and attitudes toward microcomputers among managers", International Journal of Man-Machine Studies, (32), 3: 327-340.

Pavlou, P. A. (2002). "Consumer Acceptance of Electronic Commerce: Integrating Trust and Risk with the Technology Acceptance Model", International Journal of Electronic Commerce, (7), 3: 101-134.

Rammstedt, B., John, O. P. (2007). "Measuring personality in one minute or less: A 10item short version of the Big Five Inventory in English and German", Journal of Research in Personality, (41), 1: 203-212. doi:/10.1016/j.jrp.2006.02.001

Regan, P. M. (2002). "Privacy as a Common Good in the Digital World", Information, Communication \& Society, (5), 3: 382-405.

Salgado, J. F., Moscoso, S., Lado, M. (2003). "Evidence of cross-cultural invariance of the big five personality dimensions in work settings", European Journal of Personality, (17), 1: 67-76.

Smith, J. H., Milberg, S. J., Burke, S. J. (1996). “Information Privacy: Measuring Individuals' Concerns about Organizational Practices", MIS Quarterly, (20), 2: 167-196.

Stewart, K. A., Segars, A. H. (2002). "An Empirical Examination of the Concern for Information Privacy Instrument”, Information Systems Research, (13), 1: 36-49.

Sumner, C., Byers, A., Shearing, M. (2011). "Determining personality traits \& privacy concerns from Facebook activity”, Black Hat Briefings, (11): 197-221.

Thomas, J. (1994). "Factors affecting computer anxiety and its effects on ease of use of business software. Managing Social and Economic Change with Information Tech- 
nology", u: Proceedings of 1994 Information Resources Management Association. International Conference, Mehdi Khosrowpour, London, U.K.: IDEA Group Publishing, p. 51-52.

Tupes, E.C., Christal, R.E. (1961). "Recurrent personality factors based on trait ratings", USAF ASD Tech. Rep. No. 61-97, Lackland Airforce Base, TX: U. S. Air Force. Available at: http://www.dtic.mil/dtic/tr/fulltext/u2/267778.pdf (last accessed 20.3.2017)

Ur, B., Wang, Y. (2013). "A cross-cultural framework for protecting user privacy in online social media", u: Proceedings of the $22^{\text {nd }}$ international conference on World Wide Web companion, International World Wide Web Conferences Steering Committee, p. 755-762. doi:10.1145/2487788.2488037

Viseu, A., Clement, A., Aspinall, J. (2004). "Situating Privacy Online", Information, Communication \& Society, (7), 1: 92-114.

Zhang, Y., Chen, J., Wen, K. (2002). "Characteristics of internet users and their privacy concerns - a comparative study between China and the United States", Journal of Internet Commerce, (1), 2: 1-16.

\section{UTJECAJ OSOBINA LIČNOSTI NA ZABRINUTOST ZA PRIVATNOST U ONLINE OKRUŽENJU}

Sažetak

Ovaj rad istražuje osobine ličnosti kao odrednice zabrinutosti za privatnost u online okruženju. Cilj istraživanja je analizirati utječu li i na koji način osobine korisnika Interneta na njihovu zabrinutost za privatnost u online okruženju, pri čemu se koristi teorijski okvir pet osobina ličnosti. Model također uključuje niz drugih varijabli koje mogu utjecati na online zabrinutost o privatnosti, kao što su socio-demografski čimbenici, kulturne vrijednosti i računalna pismenost. Empirijska analiza temelji se na podacima prikupljenim u 2016. godini na uzorku od 2060 korisnika Interneta u Hrvatskoj. Rezultati OLS i probit modela pokazuju da dvije dimenzije osobina ličnosti, ekstrovertiranost i neurotičnost, značajno određuju razinu zabrinutosti za privatnost u online okruženju. Više ekstrovertirani korisnik Interneta je manje zabrinut za svoju privatnost na Internetu, dok je neurotičnija osoba više zabrinuta. Svijest o privatnosti, anksioznost u korištenju računala i prethodno (negativno) iskustvo također imaju pozitivan utjecaj na razinu zabrinutosti za privatnost korisnika Interneta.

Ključne riječi: zabrinutost za privatnost, Internet, osobine ličnosti, anketa 